\title{
岱庄煤矿充填 9 轨顺区域通风系统优化技术的研究
}

\section{Study on Optimization Technology of Ventilation System for Filling 9 Rail Shun Area in Daizhuang Coal Mine}

\author{
董 健 $^{1}$ 房其贤 $^{2}$ 彭振生 $^{2}$ 郝 飞 $^{2}$ \\ Jian Dong ${ }^{1}$ Qixian Fang ${ }^{2}$ Zhensheng Peng ${ }^{2}$ Fei $\mathrm{Hao}^{2}$ \\ 1. 山东天安安全检测技术服务有限公司 山东 淄博 255120 \\ 2. 㵽博矿业集团有限责任公司岱庄煤矿 山东 济宁 272175 \\ 1. Shandong Tian 'an safety testing Technology Service Co Ltd Zibo Shandong 255120 \\ 2. Daizhuang Coal Mine, Zibo Mining Group Co Ltd Jining Shandong 272175
}

摘 要: 矿井采空区漏风或造成其他地点风量减少, 引起采空区遗煤自燃, 严重影响矿井通风系统的稳定性。本项目针对矿 井高负压区域采空区的漏风现象尤为严重的现状,通过调整通风设施的手段, 实现采空区两侧密闭均压。有效杜绝了采空区 漏风现象。

\begin{abstract}
: the air leakage in goaf or the reduction of air volume in other places cause spontaneous combustion of coal left in goaf and seriously affect the stability of mine ventilation system. In view of the serious air leakage phenomenon in the goaf of high negative pressure area of mine, this project realizes the airtight equal pressure on both sides of the goaf by adjusting the ventilation facilities. Effectively put an end to the phenomenon of air leakage in goaf.
\end{abstract}

关键词: 凤流控制;平衡压差;采空区

Keywords : air flow control; balance pressure difference; goaf

DOI : $10.36012 /$ etr.v2i12.3038

\section{1.项目立项背景}

充填 9 面是矿井在-315 辅助水平西翼区域布置的第二 个亳体充填采煤工作面, 改工作面紧邻充填 10 面, 与充填 10 面共用一条皮带顺槽。因此,该工作面只需要掘进充填 9 面轨道顺槽。

充填 9 面轨道顺槽从 1311 轨道顺槽开门口，掘进工作 面的局扇安设在 -315 辅助水平西翼轨道大巷，沿-315 辅助 水平西翼各采煤工作面采空区边缘掘进。掘进工作面回风经 过充十沉淀池, 进入-315 辅助水平西翼胶带大巷。由于工作 面为设计皮带顺槽, 充填 9 轨道顺槽掘进完成后, 无法形成 独立通风。根据现有的巷道布置, 只能将充 9 轨道顺槽作为 并联回风道进行通风。
这种通风布局方式, 存在以下缺点: (1)不能实现充填 9 轨道顺槽独立通风, (2) 充填 10 工作面变成 1 进 2 回的通风 方式, 调风变得困难, 为保证各顺槽的风量、风速, 需要额外 增加很大一部分充填十面的进风量, 造成风量浪费。

\section{2.项目研究的主要内容}

\section{1 优化前的通风系统}

优化前, 充填 9 轨道顺槽作为充填十面的并联回风道进 行通风( 如图 1 所示),加之矿井 -315 辅助水平西翼轨道大 巷的回风也流经充填 10 面轨道顺槽。这样, 充填 10 面皮带 顺槽负担着 3 处用风地点的通风。风量调整工作异常困难, 想要保证各地点的用风量, 加大充填 10 轨道顺槽的进风量, 这样造成风量浪费的现象就在所难免。 


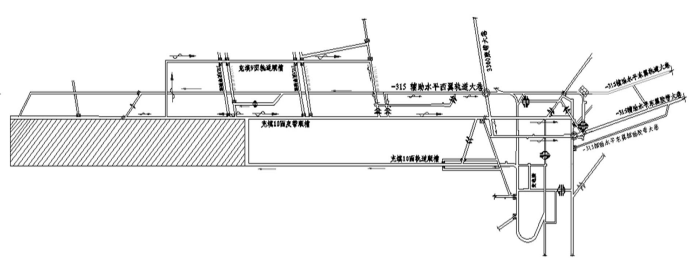

图 1

如图 1 所示: 该区域通风线路有两条分别是:

(1) 充填 10 轨道顺槽 $\rightarrow$ 充填 10 工作面 $\rightarrow$ 充填 10 皮带 顺槽 $\rightarrow-315 \downarrow$

充填 10 面沉淀池通道七充填 9 轨道顺槽

辅助水平西翼胶带大巷外段。

(2) -315 辅助水平西翼轨道大巷 $\rightarrow-315$ 辅助水平西翼 轨道大巷联络巷 $\rightarrow-315$ 辅助水平西翼胶带大巷里段 $\rightarrow$ 充填 10 面轨道顺槽 $\rightarrow-315$ 辅助水平西翼胶带大巷外段。

这种条件下: 充填十面轨道顺槽需配进风 $1500 \mathrm{~m} 3 / \mathrm{min}$ 才能满足充填 10 面皮带顺槽和充填 9 面轨道顺槽的风量。 -315 辅助水平西翼轨道大巷里段需要配风 $108 \mathrm{~m} 3 / \mathrm{min}$ 。

\section{2 优化后的通风系统}

通过合理构筑通风设施, 将充填 9 轨道顺槽成为独立通 风的巷道, 巷道单独进风, 风量自主调控, 巷道只需要按照最 低风速配风即可。

(图 2 所示)。

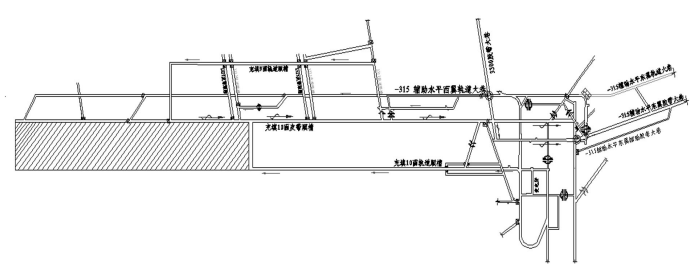

图 2

具体的做法为: 将 1309 轨道下山底盘的风门拆除, 这样 充填 9 面轨道顺槽通过 1309 轨道下山与-315 辅助水平西 轨大巷相连接, 在充十沉淀池和 1311 轨顺联络巷处构筑风
门, 实现充填 9 面轨道顺槽独立进风。将-315 辅助水平西 轨大巷和西胶大巷里段封闭, 减少风量浪费。

如图所示: 该区域通风线路有两条, 分别是:

(1) 充填 10 轨道顺槽 $\rightarrow$ 充填 10 工作面 $\rightarrow$ 充填 10 皮带 顺槽 $\rightarrow-315$

辅助水平西翼胶带大巷外段。

(2) 充填 9 轨道顺槽 $\rightarrow$ 充填 9 切眼 $\rightarrow$ 充填 10 皮带顺 槽 $\rightarrow-315$ 辅助水平西翼胶带大巷外段。

这种条件下: 充填 10 轨道顺槽需配进风 $950 \mathrm{~m} 3 / \mathrm{min}$ 。另 充填 9 轨道顺槽需单独配风 $150 \mathrm{~m} 3 / \mathrm{min}$ 。 -315 辅助水平西 翼轨道大巷里段封闭, 无需配风。

因此,该项目可节省风量: 1500+108-(950+150)= $508 \mathrm{~m} 3 / \mathrm{min}$ 。

\section{3.项目的主要创新点}

此项技术的主要创新点为:

1、降低了矿井的需要风量, 减少了风机电耗, 节约了矿 井风量成本, 达到了节本降耗的目的。

2、实现了充填 9 轨道顺槽独立通风, 区域通风系统更加 合理稳定。

3、进一步提高了通风系统的可靠性，。

4、为矿井今后在老巷道区域掘进和扩修条件下通风系 统优化工作提供了新思路。

\section{4.项目实际应用效果}

该技术已在充填 9 轨道顺槽区域实际应用, 充填 9 切眼 贯通充填 10 皮带顺槽后, 及时按照本技术的方法进行了通 风系统优化, 节约了风量, 且有效保证了区域通风系统合理、 稳定。

\section{参考文献}

[1] 杨惠钧. 矿井通风技术及通风系统优化设计研究[J].石化技术. $2019(02)$

[2] 黄元金. 矿井通风技术及通风系统优化设计研究[J].内蒙古煤炭 经济.2016(24)

[3] 刘建军.井下通风系统优化实践分析[J].能源与节能.2016(12) 